This is an Accepted Manuscript of an article published by Wiley in Population,

Space and Place on 11 May 2015, available online:

http://onlinelibrary.wiley.com/doi/10.1002/psp.1932/abstract

\title{
Escaping Homelands with Limited Employment and Tertiary Education Opportunities: Outbound Student Mobility from Post-Soviet Countries
}

Maia Chankseliani*

\begin{abstract}
Despite the phenomenal growth in the numbers of international students, research focusing on mobile students from post-Soviet countries is still extremely scarce. This paper offers an empirical investigation and theorisation of student mobility from postSoviet countries to contribute to the growing body of research on the topic of international student mobility that so far has largely focused on English-speaking destination countries. Using secondary numeric data, I provide a snapshot of undergraduate student mobility differentials and examine whether particular characteristics of student home countries are associated with the proportion of their students studying abroad. The two variables of interest are the tertiary enrolments and the labour force participation of young people. The results show that countries with lower tertiary enrolments and lower labour force participation rates are more likely to have higher proportions of students studying abroad, when controlling for the population size and the GDP per capita. The regression model explains $77 \%$ of the variation in the outcome. The paper also examines the most popular destinations for students in order to show that their choices of destination countries seem to be somewhat limited and mainly revolve around countries within the region. I place the results in the context of scholarship on international student mobility and worldsystems theory to discuss the implications for individual states and individual students.
\end{abstract}

Keywords: international student mobility; post-Soviet; migration studies; comparative education; world-systems theory

\footnotetext{
*Department of Education and St. Hilda's College, University of Oxford, 15 Norham Gardens, Oxford OX2 6PY, UK. E-mail: maia.chankseliani@education.ox.ac.uk
} 


\section{Introduction}

In the context of the rapid marketisation of tertiary education and the globalisation of labour markets, progressively larger numbers of students are choosing to study abroad, with more than 4 million students studying abroad in 2012 (UNESCO, 2014a)..$^{1}$ Despite this, students remain the least studied category of migrants creating a virtually 'invisible' flow (Findlay, 2011: 168), and international student mobility (ISM) has been recognised as a rather neglected field in migration literature (King \& Raghuram, 2013). ${ }^{2}$

Within the nascent field of ISM, research focusing on mobile students from post-Soviet countries, who make up $8 \%$ of all internationally mobile students (UNESCO, 2014a), is extremely scarce. For most of the 20th century, these states constituted the Union of Soviet Socialist Republics (USSR), a country that sent very few students abroad and received foreign students primarily from other socialist countries (Barnett \&Wu, 1995). The specificity of post-Soviet countries rests with their common history throughout a large period of the past century and subsequent divergence in economic, social, political, and educational development. It may be surprising to an outsider that these countries chose heterogeneous pathways of development, leading to dissimilar educational and labour market opportunities for young people and different patterns of student mobility that are analysed and discussed in this paper.

Repressive measures that the USSR had in place did not allow its citizens to travel internationally and kept international migration well below the levels that would have occurred otherwise (Massey, 2003). The dissolution of the USSR disrupted the period of isolation from world markets, with the citizens of former Soviet countries facing fewer constrains on travel and migration. The end of the Cold War has been recognised as a pivotal event in global migration as it ended the period when world emigration rates were held low (Massey, 2003). However, to date, seven post-Soviet countries still have authoritarian governments (Economist Intelligence Unit, 2012) that continue to impose some political restrictions on travel. For example, in Belarus, a written permission from the Ministry of Education is required to pursue a study abroad opportunity (President of the Republic of Belarus, 2005).

This paper builds on the existing literature on international migration and ISM to offer an empirical investigation and theorisation of student outbound mobility from postSoviet countries. I use secondary data to provide a snapshot of undergraduate student mobility differentials and examine two domains of student mobility. First, I look at the particular characteristics of student home countries that are associated with the proportion of students studying abroad. The two variables of interest are the tertiary enrolments and the labour force participation of young people. The second domain of student mobility that the paper examines is the destination countries themselves, with a focus on the destination countries within the region. The analyses deliver estimates to explain potential reasons for differences in student mobility in post-Soviet settings. The implications of empirical findings for individual students and individual states are discussed through the lenses of ISM and world-systems theory (WST). 


\section{International Student Mobility and World-Systems Theory}

Migration is a universal experience and students represent a well-defined group of migrants. In this section, I synthesise selected arguments from ISM literature with basic 'scientific truths' (Massey, 2003) about international migration and with WST to make an overview of the existing evidence on the role of macrofactors in the outbound student mobility (OSM) from post-Soviet countries.

The world system, as conceptualised by Immanuel Wallerstein in the 1970s, was established during the 16th century and assumes the existence of one world that is connected by economic relationships. This system is based on the main idea of the capitalist economy - competing agents' strive to the accumulation of capital. The world system consists of economically advanced countries, called core countries, and economically disadvantaged countries, called peripheries. The core countries focus on maintaining their advantageous position in the world system where the upward movement of peripheral countries is extremely unlikely. There is the third type of countries that lies between core and periphery. Wallerstein calls them semi-peripheral states (Wallerstein, 2004). ${ }^{3}$

World-systems theory views international migration in terms of a flow from the periphery to the core. Peripheral countries are poor and weak, core countries are rich and powerful, and semiperipheral states are somewhere in the middle, rather diverse economically and politically (Wallerstein, 1974, 1976). In the light of WST, the absolute majority of post-Soviet countries are peripheral. Russia is an exception; according to structuralist scholarship, it is a semi-periphery (Babones, 2013) that acts in part 'as a peripheral zone for core countries and in part [...] as a core country for some peripheral areas' (Wallerstein, 1976: 463). While being peripheral for the core countries, Russia is a core country for post-Soviet states. This central position in the region may stem from Russia's political and economic role in the Russian empire and the USSR, as well as its size and wealth.

Country size and economic development are two of the four micro factors that I use in this paper as covariates to understand the role of independent variables - tertiary gross enrolment ratio (GER) and youth employment rates in the home country - in explaining the variation in the OSM. Besides these external circumstances, a variety of individual characteristics and family level conditions affect the volume of mobile students. The existing literature has primarily focused on the micro aspects of individual decisionmaking rather than on the wider socioeconomic, educational, and cultural contexts that may be associated with such decisions (Findlay, 2011; Van Mol \& Timmerman, 2014). Immigration is a natural consequence of broader social, political, and economic processes across international borders (Massey, 2003), and these macro processes can serve as push and/or pull factors for large numbers of young people to migrate. Besides the four factors mentioned previously, some of these macrofactors may also relate to pre-existing migrant stocks, political conditions, colonial linkages, ties between countries, teaching language, and availability of scholarships. The choice of the two independent variables for this study was determined by the hypothesis that the tertiary system capacity and employment opportunities in students' home countries may be associated with the proportion of students studying abroad. 
The results of studies on the relationship between domestic tertiary system capacity and outbound mobility are conflicting. Some authors (Lee \& Tan, 1984; Altbach et al., 1985; McMahon, 1992) show that unmet demand for higher education (HE) pushes students to seek educational opportunities abroad, whereas others do not establish significant relationships between the two variables (Naidoo, 2007). Martin and Bray (2009) examine small states internationally to conclude that there is a negative relationship between the outbound mobility ratio (OMR) and the GER in small states; on average, countries with higher GER have lower OMR. However, the relationship is not consistent across different regions with the outbound mobility being either a complement or a substitute for the domestic provision of HE in different parts of the world.

The influence of the quality of HE opportunities in the home country on student mobility is also contested. Whereas Rosenzweig (2008) argues that improvements in the quality of home country HE institutions (HEIs) decreases student outflows, Perkins and Neumayer (2014) demonstrate a comparatively small influence of HEI quality on student inflows internationally and argue that the substantive importance of quality in attracting overseas students is overstated. As measured by international rankings, Russia offers the best-quality HE opportunities in the region.

According to the Shanghai Ranking, also known as the Academic Ranking of World Universities (ARWU), Russia is the only post-Soviet country with two universities on the list of the top 500 (ARWU, 2013). With the 'invisible hands' of the market driving HEIs to promote their products globally, HEI rankings are becoming increasingly important, as good indicators of the financial benefits provided by attendance at an HEI (Hazelkorn, 2008). These two universities would qualify Russia as the core country in the region, according to WST. 'The academic world has always been characterised by centers and peripheries. Countries have attained stronger universities than others for a variety of reasons because of their wealth, long academic traditions, size, language, and other factors [...] are seen as centers' (Altbach et al., 2009: 10).

The relationship between OMR and the second macrofactor of interest - labour market opportunities - may be viewed from the point of view of three potential assumptions that students may be making. First, study abroad may be linked with their intention/propensity to stay in the destination country for work experience, short term, or permanent employment. Second, study abroad may be linked with gaining positional advantage at a student's home country labour market. Third, study abroad may be associated with higher chances of or more gainful employment abroad, in a third country. Empirical literature looking at geographic contexts other than post-Soviet states shows the plausibility of all of these possibilities. ${ }^{4}$

Traditional literature conceptualises links between international migration and labour markets by using push-pull models (Todaro \& Maruszko, 1987). Most international moves are prompted by migrants' desire to deal with economic problems at home, in response to income risk and/or the failures in different markets (insurance, credit, and labour), with the size of wage differential being not the only or the most important factor that may push people to migrate (Massey et al., 1993). Therefore, new economics of labour migration (that focuses on failures in capital, credit, futures, and insurance markets) is considered to be more useful than neoclassical economics (that largely relies on using wage differentials) to explain the migration behaviour of individuals 
(Massey, 2003). Van Mol and Timmerman (2014) show that mobile students at European HEIs are influenced by macroeconomic factors, such as labour market opportunities at home and abroad. Some students expect direct economic returns from study abroad as they combine study with part-time work. Others view study abroad as a way of coping with uncertainties in their home country labour markets by improving their future labour market opportunities. Although there have been studies that attempt to establish linkages between study abroad decisions and students' intentions for labour migration (Tremblay, 2005; Hazen \& Alberts, 2006; Rosenzweig, 2008; Hawthorne, 2010; Robertson, 2011), there is little empirical evidence on the associations between home country labour market conditions and the propensity of study abroad in post-Soviet settings.

When looking at various macro factors as pulling forces for international students, it is important to note that individuals are not expected to 'scatter randomly' across the world; neither do they move to the nearest wealthy country. They choose destinations considering economic, social, and/or political links between home and destination countries (Massey, 2003). In this respect, application of WST to the study of international migration results into a number of hypotheses: Global economy's penetration into peripheral countries and formation of capitalist markets are catalysts for international migration. International labour migration follows international flow of capital; however, these two flows are in opposite directions. It is the structure of the global economy and the dynamics of market creation and not specific wage differentials that are decisive when it comes to movements of people. Former colonies and past colonial powers develop migration links naturally because of the existing linguistic, cultural, and communication connections between them (Massey et al., 1993: 448).

Relational ties stemming from durable colonial linkages are important when it comes to understanding ISM (Lee \& Tan, 1984; Perkins \& Neumayer, 2014), as former colonial powers try to retain their hegemonic position by using their connections to attract students from their dependence (Kell \& Vogl, 2008). Although post-communism has been overlooked in Western post-colonial studies (Moore, 2006; Kołodziejczyk \& Şandru, 2012), literature has recognised the Russian empire and the USSR that succeeded it as comparable to other European colonial empires. ${ }^{5}$ The USSR, to which Russia is a successor and the legal heir, expanded its political influence by implementing a number of Russification policies. These included imposing the Russian language as the lingua franca and educating the selected individuals in the colonial capital to develop human resources that would serve the colony in the future.

Diaspora linkages, which in this region may also be related to the colonial past, could also contribute to student choices. Migration literature talks about the 'family and friends' effect of immigrant concentration in certain areas that helps to channel and incorporate new arrivals to the same area; networks expand and self-perpetuate, supporting and sustaining additional movement of people, according to the theories of cumulative causation and social capital (Massey, 2003). The diaspora effect has been recognised as one of the central effects that may outweigh the importance of colonial links when it comes to student mobility as it can translate into 40-55\% lower living costs for international students (Beine et al., 2014).

Skilled individuals can reap significant benefits by migrating from high-emigration countries; most of these benefits relate to gains in individual income and human capital 
(Gibson \& McKenzie, 2012), with international migration from poor to rich countries 'becoming more of the brain drain type' (Docquier \& Rapoport, 2012: 725). Brain drain is a term used to refer to high-skill migration as a negative outcome for a nation-state. There are two approaches to brain drain in terms of its implications for sending counties. The pessimists argue that brain drain may result into permanent reduction in income and growth for the country of origin and allow rich countries to benefit at the expense of relatively underdeveloped economies. ${ }^{6}$ Scholars from a more neutral/optimistic camp disagree that the affects of brain drain can only be negative, as skilled migrants may keep assets in home countries, send remittances, and/or generate positive network externalities such as knowledge transfer. ${ }^{7}$ Some authors even argue that migration prospects may be beneficial for countries as they may foster private educational investments at home (Beine et al., 2008; Batista et al., 2012). As wages for skilled workers are higher in developed countries, the possibility of migrating to those countries increases the expected private returns on the investment in human capital in developing countries. Obviously, not everyone who invests in their education in a developing country migrates to a developed country. Also, not everyone who migrates stays abroad permanently.

Acknowledging the importance of studying ISM, King and Raghuram (2013) suggest that future research, amongst other priorities, needs to focus both on the statistical analysis of ISM datasets and developing greater theoretical insights. This article uses the relevant empirical data and theoretical literature to show that in the post-Soviet context, OSM may be explained by the availability of tertiary education and jobs in students' home countries. The analysis of availability can include the examination of the availability of opportunities by type, quality, or attractiveness. This article takes a standpoint of physical availability as indicated by tertiary enrolments and labour market participation rates of young people in the selected 14 countries. ${ }^{8}$ With only $20 \%$ of 15-24 year olds employed in Moldova and only 31\% employed in Lithuania (World Bank, 2013a), with 9\% of tertiary GER in Uzbekistan and 20\% in Azerbaijan (UNESCO, 2014c), individuals may be seeking labour market and education opportunities abroad, without focusing on the quality of opportunities as much as they focus on the availability of opportunities.

\section{Quantitative Data, Variables, and the Unit of Analysis}

The findings presented in this study arise from the analysis of secondary datasets. The dependent variable is the OMR, which is a country-level measure of the proportion of students who pursue HE overseas as a share of the total tertiary enrolments in their home country (UNESCO, 2014d). Countries with larger numbers of students studying abroad tend to have higher outbound mobility. The data were sourced from the UNESCO Institute of Statistics (UIS) dataset on outbound mobility of students at International Standard Classification of Education (ISCED) 5 and 6 (UNESCO, 2014a). These are students enrolled in a bachelor's programme or a short-cycle programme below the level of a bachelor's programme. ${ }^{9}$ According to the UNESCO definition, internationally mobile students are those who pursue undergraduate studies abroad, including those who are enrolled in a distance learning programme. These are degree mobile (pursing a HE degree) and not credit mobile (enrolled in short-term, for-credit courses and exchange programmes for less than an academic year) students. Internationally mobile students are neither citizens nor residents of the country where they study and form a 
subgroup of foreign students. The latter includes also those who are permanent residents of the destination country (UNESCO, 2014b).

Across the post-Soviet states, the average OMR is around $6.5 \%$, ranging from $13.7 \%$ in Moldova to $0.6 \%$ in Russia. As shown in Figure 1, Moldova, Azerbaijan, and Uzbekistan have the highest proportions of students studying abroad. Russia, Ukraine, and Kyrgyzstan, on the other hand, have the lowest proportions of students who choose to pursue HE outside their home countries.

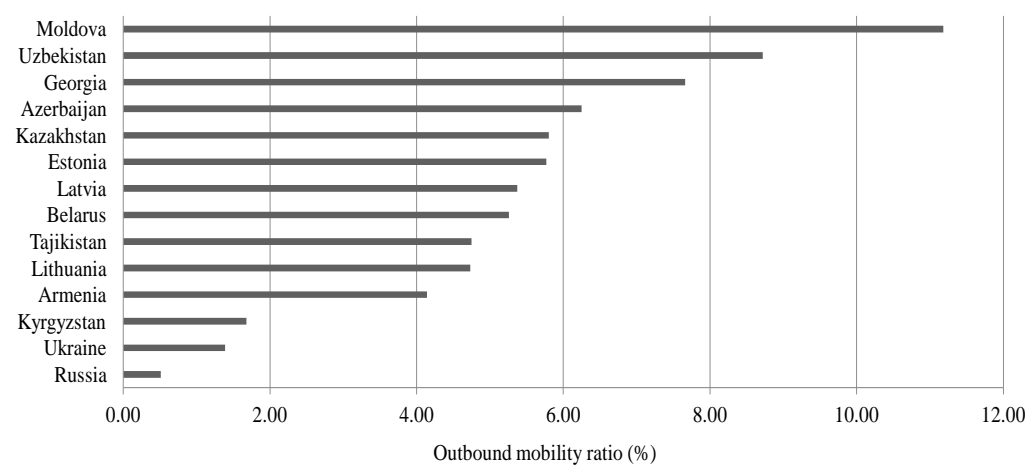

Source: own calculations based on the UNESCO (2014a) data

Figure 1. OMR in post-Soviet countries (ISCED 5 and 6; 2011).

The statistics produced by UNESCO are the only statistics on student mobility from post-Soviet countries. The data on the OMR for the majority of post-Soviet countries represent UIS estimations (UNESCO, 2014a) that are based on the data received from national statistical offices, reflecting the limitations that each country may face when collecting and reporting the data. Moreover, considering the political nature of international migration, the categories, definitions, and/or actual figures may be manipulated at the state level to 'create the appearance of some socially favoured version of reality' (Massey, 2010: 126). Finally, as explained on the UIS website, some destination countries do not specify the country of origin of mobile students, which results into underreporting of the numbers of students studying abroad (UNESCO, 2014c).

The two independent variables used in the study are tertiary GER and labour force participation among young people. GER is used as a proxy for domestic tertiary system capacity and refers to tertiary enrolments in ISCED 5 and 6 programmes, regardless of age, expressed as a percentage of the total number of students of tertiary age in the country. The tertiary age is the 5-year age group following on from when students leave secondary school. While for the majority of countries, I used the UIS data from 2012; for Kyrgyzstan and Uzbekistan, the most recent available data were from 2011 (UNESCO, 2014c). 
The World Bank's (2013a) World Development Indicators serve as the source of the data on the labour force participation rate for young people. This is a measure of the proportion of the population aged 15-24 that was economically active in 2012. All people who supply labour for the production of goods and services are considered to be economically active.

I need to make a note about the interpretation of the two independent variables. Tertiary GER and labour force participation rate are both composite variables as they bring together the supply-side and demand-side sub-factors. The tertiary GER is a composite indicator of tertiary system capacity (supply side) and tertiary aspirations (demand side). The labour force participation rate is a composite indicator of labour market opportunities (supply side) and employment aspirations (demand side). One needs to be careful when interpreting the results of regression analysis, as in this study, I use these two variables as proxies of the supply of, not the demand for, HE and jobs.

The two control variables used in the regression analysis are gross domestic product (GDP) per capita and population size, as these are shown to be important correlates of student mobility (Kritz, 2013, 2015). In the analysis, I use the statistics on GDP per capita in current US dollars for 2011. The population size is the variable that measures the total population of each country in 2012. The data are obtained from the World Bank's World Development Indicators (2013a).

This study uses nation-state as units of analysis. On the one hand, a focus on nationstates as units of analysis is considered to be a redundant or at least questionable starting point in studying spatial movements of people (Favell, 2008). On the other hand, such an approach is useful, as most of the studies on ISM are methodologically individualistic. Because the country-level variables are only averages and discount the intra-country variation, all conclusions deriving from these macro models are related to the average differences between countries. Individual students' decision-making is recognised as a complex process that is by no means reflected in the country averages. Making assumptions about individuals using aggregate data faces the threat of committing the ecological fallacy. In this paper, I avoid the ecological fallacy by recognising that aggregate databases do not account for individual, within, and between-group differences. In other words, by modelling relationships between aggregate variables, I only intend to shed light on the differences between countries and not on individuals residing in these countries.

\section{Modelling the Outbound Student Mobility from Post-Soviet Countries}

In this section, I use multiple regression analysis to model the relationships between the two independent variables (tertiary GER and labour market participation of youth), outcome variable that is OSM, and two controls (population size and GDP per capita). Before presenting the results of the modelling exercise, I examine the bivariate relationships between each predictor, control, and the outcome variable.

Post-Soviet countries vary considerably in terms of the proportion of tertiary-age population who are enrolled at HEIs. In the region, tertiary GER ranges from a relatively modest $9 \%$ in Uzbekistan to almost universal access of 91\% in Belarus. Countries with higher proportions of tertiary-age population enrolled at HEIs have lower proportions of students studying abroad (Figure 2). 


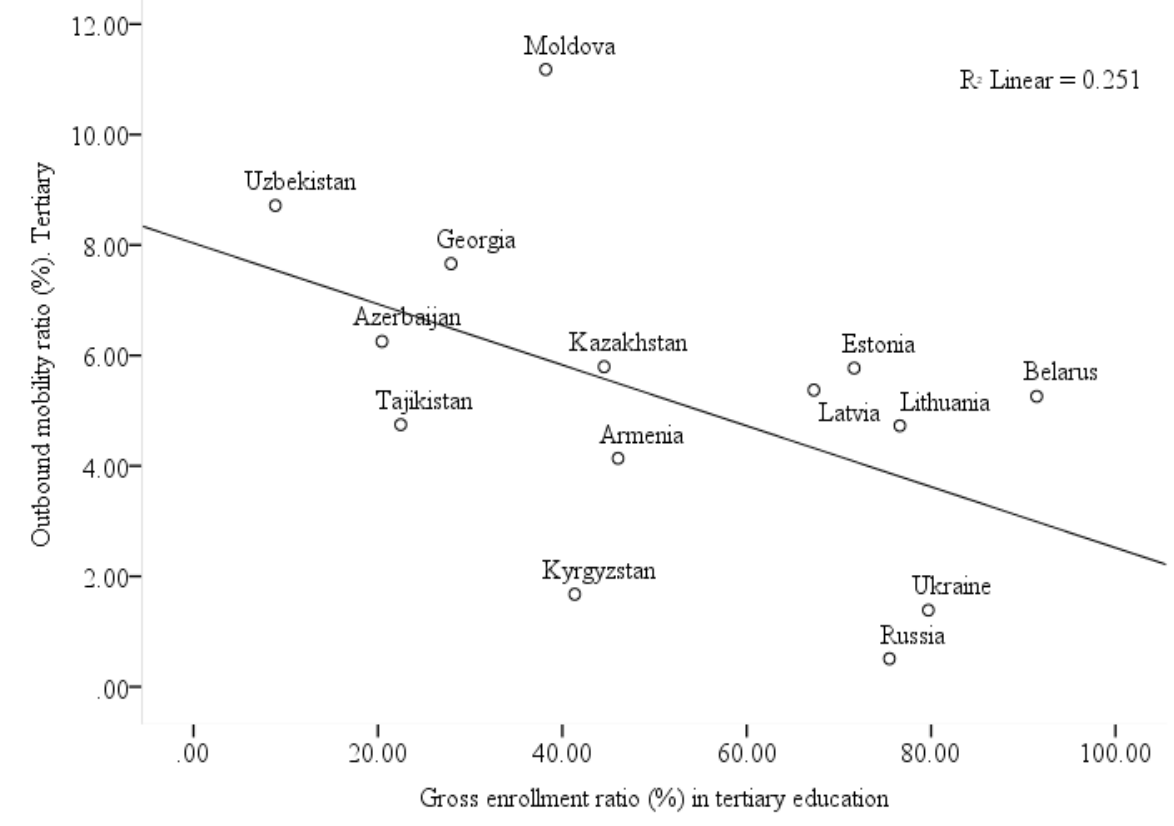

Source: own calculations based on the UNESCO (2014a, 2014b) data

Figure 2. Tertiary enrolments and outbound mobility.

The negative association between tertiary enrolments and OMR in post-Soviet settings may indicate that HE systems that can accommodate the existing demand for HE internally lead, in turn, to lower demand for pursuing HE opportunities overseas. This could be particularly true for those countries where the number of tertiary places is controlled by the government, and access to these places is highly competitive. Georgia is a good example in this respect. Considering that the Georgian HE system accommodates only $60 \%$ of all HE applicants (Chankseliani, 2013), it may not be surprising that this country has a higher OMR than what would be expected considering its GER.

Another micro factor that is associated with student mobility is labour force participation rate among young people aged 15 to 24. Post-Soviet countries with larger proportions of economically active young adults tend to have lower proportions of mobile students (Figure 3). 


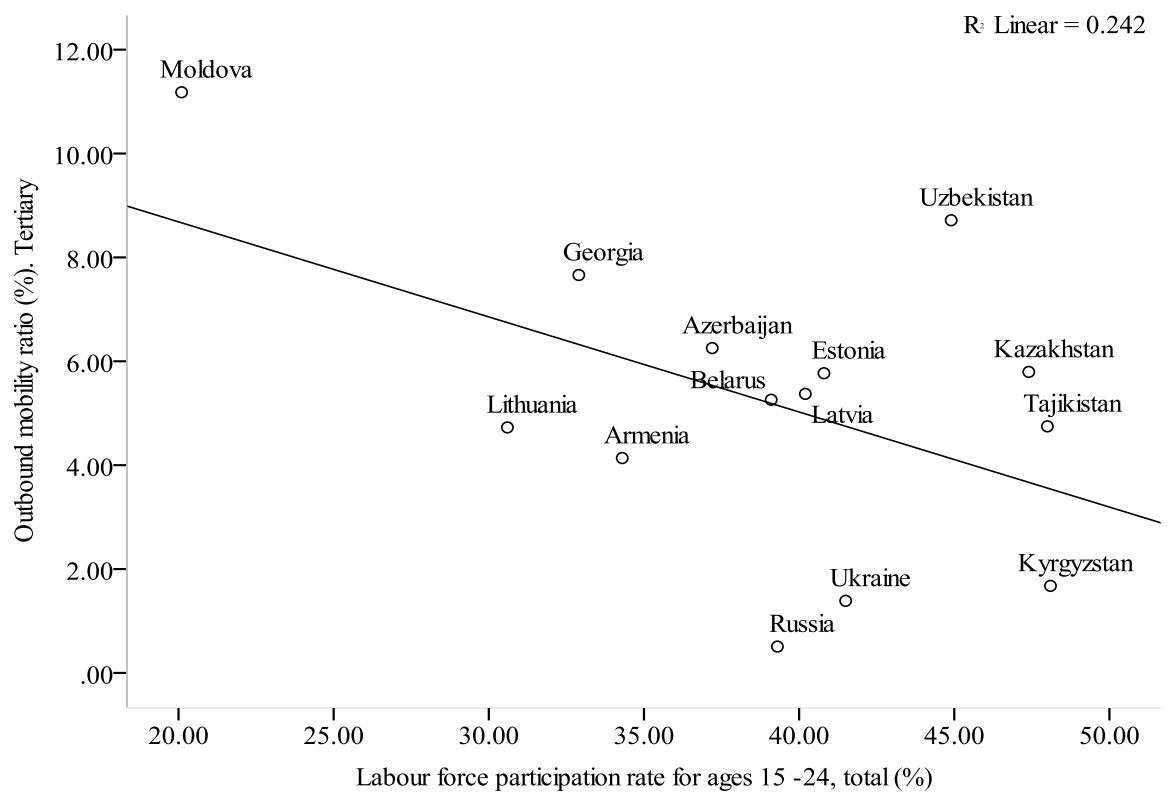

Source: own calculations based on the UNESCO (2014a), World Bank (2013a) data

Figure 3. Labour force participation rate and outbound mobility.

Former Soviet states differ dramatically in their GDP per capita. It could be hypothesised that high-income countries, like Russia and the Baltic states, are more likely to have larger proportions of well-off families who can afford study abroad, as opposed to low-income countries like Tajikistan or Kyrgyzstan. Richer countries may have more extensive government funding schemes to finance mobile students. Contrary to these expectations, correlation analysis shows that there is a negative relationship between the GDP per capita and the OMR ( $\mathrm{r}=-0.20)$; this association is not statistically significant $(\mathrm{p}=0.50)$. The funding from families or government programmes may not be the only source for financing study abroad for students in the region. Different scholarship programmes from recipient country governments, HEIs, and philanthropic organisations are also available, and the influence of such alternative sources of funding on study abroad may be considerable.

In post-Soviet states, the relationship between the total population in each country and their OMR is negative $(\mathrm{r}=-0.53, \mathrm{p}=0.05)$. Countries with larger populations tend to have lower proportions of mobile students, as a share of all tertiary students, than countries with smaller populations. More populous countries, like Russia and Ukraine, may have wider within-country choices for students, and therefore, students may be less inclined to seek HE opportunities abroad. Less populous countries, such as Moldova and Georgia, may experience more difficulties in establishing HE systems that meet the demand of those who would like to pursue HE.

Thus, those countries that have higher proportions of youth in employment or enrolled at HEIs tend to have lower proportions of young people choosing to pursue undergraduate education overseas. This finding may indicate that study abroad may serve as a potential escape in those contexts where the places at HEIs and/or 
employment opportunities may be relatively limited. Further evidence stemming from multivariate analysis confirms this relationship.

Multiple regression analysis was used to explain the OMR based on the labour force participation rate of young people and tertiary GER, when controlling for the country population size and the GDP per capita. These input variables were selected based on the research interest, supportive evidence, and logic. The statistical results of the proposed regression model are outlined in Table 1.

Table 1. Multiple linear regression modelling of OMR.

\begin{tabular}{ccc}
\hline Predictors & Model A & Model B \\
\hline $\begin{array}{c}\text { Gross tertiary enrolment } \\
\text { ratio, total (\%) }\end{array}$ & $-.491^{*}$ & $-.547^{*}$ \\
Labour force & $-.645^{* *}$ & $-.596^{* *}$ \\
participation rate, total & & \\
(\%) & & $-.391^{*}$ \\
Population total & & \\
& & .280 \\
GDP per capita (\$) & & \\
& & \\
Constant & & 20.481 \\
& 21.449 & $(3.243)$ \\
$\mathrm{N}$ & $(3.109)$ & 14 \\
$\mathrm{R}^{2}$ & 14 & 77 \\
$\mathrm{~F}$ & 59 & 7.66 \\
$(\mathrm{df})$ & 7.96 & $(4)$ \\
$\mathrm{P}$ & $(2)$ & .006 \\
$\mathrm{RMSE}$ & .007 & 2.02 \\
\hline
\end{tabular}

Source: Own calculations based on World Bank (2013a, 2013b) and UNESCO (2014a, 2014b). Note. Cell entries are standardised coefficients and significance levels as unstandardised coefficients were meaningless, potentially because of a very small sample. The main purpose of the analysis was to model the relationships and compare effects of the two independent variables, instead of establishing the precise causal relationships and calculating changes in the outcome resulting from specific changes in the predictors.

Unstandardised coefficients and standard errors are reported for constants.

${ }^{*} \mathrm{p}<0.05,{ }^{* *} \mathrm{p}<0.01$.

Model A includes only independent variables - tertiary GER and labour force

participation rate. Both variables are significant in the model, which explains 59\% of the variation in OSM. Negative signs indicate that countries with higher proportions of students enrolled at HEIs and higher proportions of employed youth, on average, have lower OMR. When the two control variables - population size and GDP per capita - are added to the two predictors, model B explains $77 \%$ of the variation in the outcome. Both predictors remain significant. Based on the standardised coefficients, tertiary GER and the labour force participation rate have a similarly strong influence on the outcome. Although only one of the control variables - population total - is significant, I retain 
both of them in model B because of their substantive importance. There is no multicollinearity in the data, as there are no substantial correlations ( $r>0.5)$ between predictors and controls. The Durbin-Watson statistic indicates that the assumption of independent errors is tenable. The F-ratio (7.66) in the ANOVA table suggests that the regression model is a good fit for the data overall $(\mathrm{p}<0.05)$. Thus, when controlling for the population size and GDP per capita, labour force participation rate and GER remain significant and explain $77 \%$ of variation in outbound mobility.

Based on the regression analysis findings, which are generally in line with previous research, 10 one could argue that students from post-Soviet countries are homines oeconomici, making rational and self-interested choices and possessing excellent information on HE systems and labour markets. Homines oeconomici seek to acquire human capital, as they are aware that educational investments result in economic benefits. The 'invisible hands' of the market drive students to seek opportunities beyond the borders of their home countries. Even under circumstances when students do not aim to stay in destination countries as labour migrants, they may believe that studying abroad will increase their chances of more profitable employment. ${ }^{11}$ I expand on the implications of these findings for individuals and states in the final section of this paper.

\section{Top Destinations for Post-Soviet Students}

The statistics on the most popular destinations for students from post-Soviet countries provide some additional evidence that reinforce the trends seen in the regression analysis. Table 2 presents top five destinations for each sending country.

Four observations emerge from this table. First, it can be discerned that the choices of destinations are rather limited. No countries from Australasia, Latin America, and Africa are on the list of the top five destinations for post-Soviet students. The popular choices are post-Soviet countries, Europe, and the USA.

Second, the number one study abroad destination for 10 out of 13 post-Soviet countries is a post-Soviet country, namely, the former coloniser - Russia. Russia emerges as the primary destination for study abroad undergraduate students from the region, followed by Kyrgyzstan, Kazakhstan, and Ukraine. This may be explained by Russia's position as a core country for post-Soviet states. This central position in the region may stem from Russia's political and economic role in the Russian empire and the USSR. Russia is large, wealthy, compatible language-wise, and accommodating because of the diaspora effect. Russia also offers the best-quality HE across the post-Soviet space, as measured by international rankings. According to the Shanghai Ranking, Russia is the only postSoviet country with two universities on the list of the top 500 (ARWU, 2013).

Table 2. The most popular destination countries 


\begin{tabular}{|c|c|c|c|c|c|c|}
\hline $\begin{array}{l}\text { Home } \\
\text { countries }\end{array}$ & $\begin{array}{l}\text { Outbou } \\
\text { nd } \\
\text { mobilit } \\
\text { y ratio }\end{array}$ & $\begin{array}{l}\text { Destination } \\
\text { country I }\end{array}$ & $\begin{array}{l}\text { Destination } \\
\text { country II }\end{array}$ & $\begin{array}{l}\text { Destination } \\
\text { country III }\end{array}$ & $\begin{array}{l}\text { Destination } \\
\text { country IV }\end{array}$ & $\begin{array}{l}\text { Destination } \\
\text { country V }\end{array}$ \\
\hline Moldova & 13.7 & $\begin{array}{l}\text { Russia* } \\
\text { (5575) }\end{array}$ & $\begin{array}{l}\text { Romania } \\
(5502)\end{array}$ & $\begin{array}{l}\text { Italy^ } \\
(1815)\end{array}$ & $\begin{array}{l}\text { France }^{\wedge} \\
(1001)\end{array}$ & $\begin{array}{l}\text { Ukraine* } \\
\text { (895) }\end{array}$ \\
\hline Azerbaijan & 10.9 & $\begin{array}{l}\text { Russia* } \\
\text { (12161) }\end{array}$ & $\begin{array}{l}\text { Turkey } \\
(4412)\end{array}$ & $\begin{array}{l}\mathrm{UK}^{\wedge} \\
(574)\end{array}$ & $\begin{array}{l}\text { Germany }{ }^{\wedge} \\
(511)\end{array}$ & $\begin{array}{l}\mathrm{USA}^{\wedge} \\
(446)\end{array}$ \\
\hline Uzbekistan & 9.0 & $\begin{array}{l}\text { Russia } \\
\text { (11343) }\end{array}$ & $\begin{array}{l}\text { Kyrgyzstan* } \\
(5967)\end{array}$ & $\begin{array}{l}\text { Kazakhstan* } \\
(2898)\end{array}$ & $\begin{array}{l}\text { Tajikistan* } \\
(824)\end{array}$ & $\begin{array}{l}\text { Germany } \\
(779)\end{array}$ \\
\hline Georgia & 8.5 & $\begin{array}{l}\text { Russia* } \\
\text { (2343) }\end{array}$ & $\begin{array}{l}\text { Germany }{ }^{\wedge} \\
\text { (1919) }\end{array}$ & $\begin{array}{l}\text { Armenia* } \\
\text { (1051) }\end{array}$ & $\begin{array}{l}\text { USA }^{\wedge} \\
(466)\end{array}$ & $\begin{array}{l}\text { France } \\
(427)\end{array}$ \\
\hline Lithuania & 7.1 & $\begin{array}{l}\mathrm{UK}^{\wedge} \\
(4916)\end{array}$ & $\begin{array}{l}\text { Denmark } \\
\text { (1573) }\end{array}$ & $\begin{array}{l}\text { Germany } \\
(971)\end{array}$ & $\begin{array}{l}\text { Poland } d^{\wedge} \\
(942)\end{array}$ & $\begin{array}{l}\text { Russia* } \\
\text { (745) }\end{array}$ \\
\hline Estonia & 7.0 & $\begin{array}{l}\mathrm{UK}^{\wedge} \\
(1223)\end{array}$ & $\begin{array}{l}\text { Finland*^} \\
(772)\end{array}$ & $\begin{array}{l}\text { Russia* } \\
(618)\end{array}$ & $\begin{array}{l}\text { Germany } \\
(540)\end{array}$ & $\begin{array}{l}\text { Denmark }^{\wedge} \\
(325)\end{array}$ \\
\hline Belarus & 6.9 & $\begin{array}{l}\text { Russia* } \\
\text { (31199) }\end{array}$ & $\begin{array}{l}\text { Poland*^} \\
(2991)\end{array}$ & $\begin{array}{l}\text { Lithuania* } \\
\text { (1989) }\end{array}$ & $\begin{array}{l}\text { Germany } \\
(1364)\end{array}$ & $\begin{array}{l}\text { Czech Republic } \\
(527)\end{array}$ \\
\hline Latvia & 6.8 & $\begin{array}{l}\mathrm{UK}^{\wedge} \\
(2232)\end{array}$ & $\begin{array}{l}\text { Russia* } \\
\text { (924) }\end{array}$ & $\begin{array}{l}\text { Denmark } \\
(749)\end{array}$ & $\begin{array}{l}\text { Germany } \\
(627)\end{array}$ & $\begin{array}{l}\text { Netherlands } \\
(398)\end{array}$ \\
\hline Kazakhstan & 6.6 & $\begin{array}{l}\text { Russia* } \\
(29865)\end{array}$ & $\begin{array}{l}\text { Kyrgyzstan } \\
(3107)\end{array}$ & $\begin{array}{l}\mathrm{UK}^{\wedge} \\
(2014)\end{array}$ & $\begin{array}{l}\mathrm{USA}^{\wedge} \\
(1877)\end{array}$ & $\begin{array}{l}\text { Czech Republic } \\
(979)\end{array}$ \\
\hline Armenia & 5.8 & $\begin{array}{l}\text { Russia } \\
(4240)\end{array}$ & $\begin{array}{l}\text { France } \\
(888)\end{array}$ & $\begin{array}{l}\mathrm{USA}^{\wedge} \\
(352)\end{array}$ & $\begin{array}{l}\text { Germany } \\
(347)\end{array}$ & $\begin{array}{l}\text { Greece }^{\wedge} \\
(211)\end{array}$ \\
\hline Tajikistan & 4.7 & $\begin{array}{l}\text { Russia } \\
(6226)\end{array}$ & $\begin{array}{l}\text { Kyrgyzstan* } \\
(1196)\end{array}$ & $\begin{array}{l}\text { Kazakhstan* } \\
(397)\end{array}$ & $\begin{array}{l}\mathrm{USA}^{\wedge} \\
(289)\end{array}$ & $\begin{array}{l}\text { Turkey } \\
(277)\end{array}$ \\
\hline Kyrgyzstan & 2.2 & $\begin{array}{l}\text { Russia* } \\
(2663)\end{array}$ & $\begin{array}{l}\text { Turkey } \\
(785)\end{array}$ & $\begin{array}{l}\text { Germany } \\
(534)\end{array}$ & $\begin{array}{l}\text { Kazakhstan } \\
(354)\end{array}$ & $\begin{array}{l}\mathrm{USA}^{\wedge} \\
(246)\end{array}$ \\
\hline Ukraine & 1.7 & $\begin{array}{l}\text { Russia* } \\
(12805)\end{array}$ & $\begin{array}{l}\text { Poland }{ }^{\star \wedge} \\
(6118)\end{array}$ & $\begin{array}{l}\text { Germany } \\
(5875)\end{array}$ & $\begin{array}{l}\text { Italy } \\
(1780)\end{array}$ & $\begin{array}{l}\text { Czech Republic } \\
\text { (1727) }\end{array}$ \\
\hline Russia & 0.6 & $\begin{array}{l}\text { Germany } \\
(10007)\end{array}$ & $\begin{array}{l}\mathrm{USA}^{\wedge} \\
(4654)\end{array}$ & $\begin{array}{l}\text { France ^ } \\
(4300)\end{array}$ & $\begin{array}{l}\mathrm{UK}^{\wedge} \\
(3574)\end{array}$ & $\begin{array}{l}\text { Ukraine* } \\
\text { (2990) }\end{array}$ \\
\hline
\end{tabular}

Source: Own calculations based on the UNESCO (2014a) data.

Note. The number of students from a given country studying in the destination countries is shown in brackets.

* denotes a neighbouring country.

$\wedge$ denotes OECD countries

Kyrgyzstan is the second most favoured destination for three out of 13 countries. Kazakhstan is one of the five most favoured destination countries for three out of 13 countries, and Ukraine for two out of 13. As such, the post-Soviet countries that are the most popular destinations for regional students are the countries with very low outbound mobility. Russia, Ukraine, and Kyrgyzstan have the smallest proportions of tertiary students studying abroad (Figure 1). Being popular destinations among students from the region, these three countries apparently have sufficient capacities to meet the demand for HE originating not only internally but also externally. This trend 
supports the earlier suggestion that post-Soviet countries with limited outbound mobility may have higher capacities at the tertiary level.

Third, neighbouring countries seem to make up, on average, two out of five most popular destinations for post-Soviet countries. This finding confirms the importance of geographic distance for student mobility (González et al., 2011; Perkins \& Neumayer, 2014). Uzbekistan and Belarus are the leaders in this respect; three out of five most popular destinations for students from these two countries are across the borders. Armenia is the only exception, as undergraduates from this country do not seem to favour any of the neighbouring countries as a top five destination.

Fourth, the top destination countries are generally economically more appealing than the country of origin. For the purposes of this study, GDP per capita and membership to Organisation for Economic Co-operation and Development (OECD) are used as indicators of economic development. In eight out of 14 country cases, all top five destinations are economically more advanced than the country of origin, that is, most of the students are 'vertically' mobile, following Teichler's (2012: 9-10) definition and using GDP per capita as the indicator of economic development. There are exceptions, such as having Russia as one of the top destinations for Baltic states and Ukraine as one of the destinations for Russian students. Also, there are two cases when students from Central Asian countries (Uzbekistan and Kazakhstan) choose to study in a less economically advanced Central Asian country. Furthermore, on average, three out of five top destinations for students from post-Soviet countries are OECD countries. Considering that half of the world's total immigration and $85 \%$ of high-skill migration fall on OECD countries (Docquier \& Rapoport, 2012), this is not a surprising finding. However, in contrast to the global trends in student mobility (Varghese, 2008), students from post-Soviet countries seem to favour mostly European destinations and the USA, neglecting such popular OECD destinations, such as Australia, New Zealand, and Canada.

\section{Discussion and conclusion}

This study used the UIS data to model the OMR of students from post-Soviet countries and to link the findings with the data on the most popular destinations. In order to explicate how this evidence may advance our knowledge on ISM theoretically and practically, I examine how the results contribute to the existing literature and what they mean for individual states and individual students.

In an attempt to extend our understanding of ISM from post-Soviet countries, this paper makes the following four contributions to the ISM literature, one that has been identified as a rather neglected, nascent field in migration research (King \& Raghuram, 2013). First, this first-of-its kind study offers an analysis of the comparative trends of outbound mobility of students from post-Soviet countries, showing that there is a large variation in the proportions of students who choose to study abroad at the undergraduate level, with Russia being at the bottom (0.6\%) and Moldova at the top of the list (13.7\%). Students from the region make up $8 \%$ of the global body of internationally mobile students. Second, the paper focuses on the role of home countries' macroeconomic contexts to explain the trends of outbound mobility and thus, using the language of King and Raghuram (2013), empirically decentres the student as 
the object of the study, the regression model that explains $77 \%$ of the variation in the student outbound mobility, identifying tertiary system capacity, as proxied by GER, and labour force participation of youth as significant predictors, when controlling for population size and GDP per capita. Third, the paper maps the top five destinations for students from each post-Soviet country. The interpretation of the outcomes show that these are in line with the literature on WST and ISM, by showing that colonial ties, destination countries' economic development, HE quality, and geographic distance may be associated with destination country choices. The examination of the top destinations also shows that the post-Soviet countries that are the most popular destinations for regional students are some of the countries with very low outbound mobility; being popular destinations among students from the region, these countries apparently have sufficient capacities to meet the demand for HE originating not only internally but also externally. This trend supports the earlier suggestion that post-Soviet countries with limited outbound mobility may have higher capacities at the tertiary level.

Finally, the paper ends by offering a discussion of implications of the findings for two main actors - individual students and individual states - to argue that policies will need to accommodate the needs of individuals in the first place and to seek to engage them in ways that will allow to maximise the benefits of student mobility for individual states.

People who seek to improve their well-being may choose or be pushed to migrate in search of such opportunities. Although migration may advance lifetime opportunities of migrants, it may also result in the unequal development of nation-states, their tertiary education systems, and labour markets. I propose to interpret the regression analysis results through the lenses of these two sets of interests - those of individual students and individual states. The main assumption that I make is that individuals as well as states aim at increasing their competitiveness in the age of globalisation by investing in HE for the advancement of human capital. Following this assumption, students from post-Soviet countries are homines oeconomici who escape countries with low tertiary capacity and high youth unemployment, as confirmed by the regression model. Large proportions of mobile students from these countries seem to seek educational and employment opportunities in countries that are expected to offer good-quality HE delivered in a language that is familiar to them (Russian) and/or a language that is potentially associated with high economic returns (English). Finally, they seem to target the countries where living conditions are culturally and economically appealing.

If the investment in HE is viewed as an investment in human capital that is considered to be a central driver of individuals' and nation-states' competitiveness in the global knowledge economy, countries would be expected to invest in HE with the goal of improving domestic provision of $\mathrm{HE}$ and retaining the best talents at home. This is not the case across the board in post-Soviet countries. Government expenditure on tertiary education as a percentage of GDP is rather low in quite a few post-Soviet countries, with Armenia, Azerbaijan, Georgia, Kazakhstan, and Tajikistan investing less than $0.45 \%$ of their GDP in tertiary education (UNESCO, 2014e).

Without abundant resources, HEIs and HE systems cannot become global centres (Altbach et al., 2009). This may create a serious disadvantage for HE systems and HEIs in the peripheries. Moreover, the smaller the country, the more difficult it may find it to establish a high-quality, expansive system of HE. Although smaller post-Soviet countries do not invest a lower proportion of their GDP in tertiary education than do larger 
countries (UNESCO, 2014e), economies of scale may make it more difficult for them to provide quality HE at home. Therefore, according to Mark Bray, 'small states are almost by definition outward looking and international, [...] looking beyond their borders comes naturally to them' (Sharma, 2009). The empirical evidence on the population size and the OMR in post-Soviet countries provides some support to this argument. If the reader refers back to Figure 1 and imagines a virtual horizontal line running half way through the figure, in the top section, one would notice four small states (Moldova, Georgia, Estonia, and Lithuania), whereas in the bottom half, only two (Armenia and Latvia).

Those who believe in free markets and human capital theory may find little rationale in state support for HE. This sector, they would argue, could be supported by individuals seeking the accumulation of human capital. This is especially true for small countries where per capita costs of providing high-quality HE may be even higher than in larger countries. As governments follow the global trend of decreasing HE funding, HEIs have to adjust to the new realities of being less reliant on public funding and more dependent on attracting students from around the globe. Thus, HE becomes 'borderless' (Middlehurst, 2001).

By benefitting from borderless HE and purchasing education abroad, students and their families effectively invest in destination countries' educational systems and economies. Additionally, as a proportion of such students may stay abroad after finishing their studies or go back to the countries where they received education at later stages in their career, outbound mobility may be contributing to brain drain.

The challenge that the post-Soviet countries are facing is to design and implement policies that will help them reap benefits from student mobility and minimise the negative effects of brain drain. Gribble (2008) proposes 'retain, return, and engage' strategies for sending countries. First, such states may use the retention strategy to limit the number of students who seek educational opportunities overseas and thus decrease the probability of young people staying abroad. Second, sending countries may promote study abroad but put in place policies that will encourage young people to return to their home countries. Although there are no statistics on the proportions of students who return to their home countries, it is unlikely that students from post-Soviet countries choose study abroad as a way of eventual migration. Statistics on the desire to permanently migrate show that such motivation cannot be linked with student outbound mobility; there is no relationship between the proportion of students studying abroad and the proportion of residents who would like to permanently migrate from the countries in this region $\left(\mathrm{r}={ }_{-} 0.14, \mathrm{p}=0.68\right.$; Esipova \& Pugliese, 2013; UNESCO, 2014a). Third, sending countries may not interfere with student choices and accept that the majority will stay abroad following the completion of their degree programmes. The countries, however, may attempt to put in place policies that will allow graduates to contribute to their home countries' development by engaging from abroad (Gribble, 2008). Because 'flows cannot be effectively constrained and must instead be creatively accommodated' (Bhagwati, 2003: 99), the final - engagement option - has been recognised as the most effective strategy.

Almost half a century ago, Grubel and Scott (1966) supported the free movement of human capital; they referred to the concerns regarding negative effects of high-skilled migration on their home country's economic standing as anachronistic and maintained 
that 'individual welfare of population' should be the priority (p.274). The authors defined countries not as nationalist units but as 'an association of individuals whose collective welfare its leaders seek to maximize' and argued that the benefits of highskilled emigrants may spread to people in many countries, including their native country (p.269).

When placing the educational and employment interests of individual students above the interests of individual states, study abroad is an excellent opportunity for young people not only to acquire the human capital but also to broaden their horizons and expand their professional and personal networks. Such opportunities may be particularly valuable for those students who come from countries with a relatively low tertiary system capacity and underdeveloped labour market opportunities for young people. The question that arises here, and the one that I am unable to answer, relates to the characteristics of post-Soviet students who choose to study abroad. It is not known whether there are opportunities for the socio-economically privileged only or also for the relatively disadvantaged. Considering the European evidence, mobile students from European countries mostly originate from high socioeconomic strata (Findlay et al., 2006; Brooks \& Waters, 2011).

If the socio-economically less privileged from post-Soviet countries are largely excluded from study abroad opportunities, the globalised pursuit of HE may be reproducing (dis)advantage in these societies and increase inequality in access to HE. This may be linked to the opportunities of differentiation that the acquisition of human, social, and/or financial capital through study abroad leads to (Waters, 2006; Findlay et al., 2012; Perkins \& Neumayer, 2014).

If the trend of student mobility continues from the peripheries to the centre (Western Europe) and the semi-periphery (Russia), will it mean that less powerful societies with lower tertiary capacity and less developed labour markets may strengthen their peripheral positions? According to WST, countries remain at their original positions, with peripheral states remaining peripheral and core states remaining at the centre. This will result into HEIs in the peripheral states weakening further as the best students will seek tertiary education and potentially employment opportunities overseas.

Consequently, student migration from countries with underdeveloped labour markets and tertiary education systems may be contributing to the stagnation or deterioration of their development, on the one hand, and exacerbation of individual-level inequalities, on the other hand. However, because student mobility may provide an escape route to young people, the value that it carries for individuals who venture into a search to improve their well-being cannot be underestimated. Thus, migration is about the search for opportunities in the same way as it is about the exclusion from opportunities. Furthermore, migration can be about the escape from exclusion.

What does the future hold? Classic migration theory would argue that with the economic growth of sending countries, wage differentials diminish and markets for capital, credit, insurance, and futures develop. These decrease the incentives for individuals to migrate. As a result, the country goes through a migration transition with net outmigration decreasing and net inflow of individuals increasing (Massey, 2003: 16). However, this theory does not consider rapidly expanding international outreach programmes of HEIs across the world and the influence that these may have on the 
OMR from post-Soviet countries that may be seen as profitable yet unexploited markets for recruiting relatively well-off students. Better empirical and theoretical understanding of the factors that drive or impede student mobility from different countries in the region is required to make any predictions and to ensure that the benefits of student mobility are spread out more equally amongst different population groups and amongst different countries. As migration aspirations are formed at the intersection of a complex interplay of individual-level, institutional-level, national-level, regional-level, and international-level factors, the future research will need to utilise multi-level modelling to tease out the role of national-level factors (labour market opportunities and tertiary enrolments) in student mobility from post-Soviet countries with greater precision. While this study looked at the availability of HE and labour market opportunities for young people, the future research will need to go further by focusing on the type, quality, and attractiveness of educational and labour market opportunities and how these relate to student outbound mobility. Finally, the theorisation of ISM using WST is incomplete without attempts to explain why and how post-Soviet states act to influence OSM. The future research will need to examine such state strategies and its mechanisms.

\section{Acknoledgements}

The author would like to thank the anonymous reviewers for extremely useful feedback that they have provided during the review process.

\section{Notes}

(1) According to the UNESCO (2014b) definition, internationally mobile students are those who pursue a HE degree abroad, including those who are enrolled in a distance learning programme. These are degree mobile (pursing a HE degree) and not credit mobile (enrolled in short-term, for-credit courses and exchange programmes for less than an academic year) students. They are neither citizens nor residents of the country where they study. Internationally mobile students form a sub-group of foreign students. The latter group includes also those who are permanent residents of the destination country.

(2) As the title of this article makes obvious, I opt for the term international student mobility rather than international student migration because as follows: (a) Mobility is a broader term that may or may not assume subsequent migration and (b) the data sources used in this study use the term mobility.

(3) WST has been criticized on the basis of as follows: (a) usefulness of substituting nation-states as the unit of analysis with larger spatial/temporal zones (Wallerstein, 2004); (b) insufficient focus on politics and disproportionate reliance on the economic analysis (Brenner, 1977; Skocpol, 1977; Zolberg, 1981); (c) insufficient attention to class structure/struggle and the association between these and economic development (Brenner, 1977); and (d) limited attention to culture and overemphasis on economics (Aronowitz, 1981). 
(4) Refer to, for example, Brooks and Waters (2009), Van Mol and Timmerman (2014), Waters (2006), and Wiers-Jenssen $(2008,2013)$.

(5) Refer to, for example, Ferro (1997), Kappeler (2001), Carey and Raciborski (2004), Moore (2006), Khalid (2007), and Lazarus (2012).

(6) Refer to, for example, Bhagwati and Hamada (1974), Miyagiwa (1991), Haque and Kim (1995), Skeldon (2008), and Findlay and Tierney (2010).

(7) Refer to, for example,Grubel and Scott (1966), Berry and Soligo (1969), Johnson (1979), Docquier and Rapoport (2012), and Gibson and McKenzie (2012).

(8) The 15th country, Turkmenistan, is excluded from the quantitative analysis because of the nonavailability of data.

(9) Different factors may prompt student mobility at undergraduate and post-graduate levels (Waters \& Brooks, 2010); the selection of undergraduate student mobility was determined by the inherent interest in this group of students as well as the availability of data on undergraduate degree mobility from post-Soviet countries.

(10) Refer to, for example, Altbach et al. (1985), Lee and Tan (1984), and McMahon (1992) on the relationship between unmet demand for HE and student mobility. Refer to, for example, King and Conti (2013), Van Mol and Timmerman (2014), and WiersJenssen $(2008,2013)$ on the relationship between labour market opportunities and OMR.

(11) Seeking educational opportunities abroad may also be viewed as a consumption choice, constituting 'an internationalising geography of consumption' (Perkins \& Neumayer, 2014: 246). This article, however, focuses on the human capital perspective rather than the consumption-driven choice making.

\section{REFERENCES}

Altbach PG, Kelly DH, Lulat YG-M. 1985. Research on Foreign Students and International Study: An Overview and Bibliography. Praeger: New York.

Altbach PG, Reisberg L, Rumbley LE. 2009. Trends in global higher education: tracking an academic revolution: a report prepared for the UNESCO 2009 World Conference on Higher Education. UNESCO Division of Higher Education: Paris. Available at: http://www.uis.unesco.org/Library/Documents/trends-global-higher-education-2009world-conference-en.pdf (accessed 17 April 2014).

Aronowitz S. 1981. A metatheoretical critique of Immanuel Wallerstein's 'the modern world system'. Theory and Society 10: 503-520.

ARWU. 2013. Shanghai rankings 2013: Academic Ranking of World Universities. Available at: http://www.shanghairanking.com/ARWU-Statistics-2013.html (accessed 9 May 2014). 
Babones SJ. 2013.Astructuralist approach to the economic trajectories of Russia and the countries of East-Central Europe since 1900. Geopolitics 18: 514-535.

Barnett GA, Wu RY. 1995. The international student exchange network: 1970 \& 1989. Higher Education 30: 353-368.

Batista C, Lacuesta A, Vicente PC. 2012. Testing the 'brain gain' hypothesis: micro evidence from Cape Verde. Journal of Development Economics 97: 32-45.

Beine M, Docquier F, Rapoport H. 2008. Brain drain and human capital formation in developing countries: winners and losers. Economic Journal 118: 631-652.

Beine M, Noël R, Ragot L. 2014. Determinants of the international mobility of students. Economics of Education Review 41: 40-54.

Berry RA, Soligo R. 1969. Some welfare aspects of international migration. Journal of Political Economy 77: 778-794.

Bhagwati J. 2003. Borders beyond control. Foreign Affairs 82: 98-104

Bhagwati J, Hamada K. 1974. The brain drain, international integration of markets for professionals and unemployment: a theoretical analysis. Journal of Development Economics 1: 19-42.

Brenner R. 1977. The origins of capitalist development: a critique of neo-Smithian Marxism. New Left Review 104: 25-92.

Brooks R, Waters J. 2009. International higher education and the mobility of UK students. Journal of Research in International Education 8: 191-209.

Brooks R, Waters J. 2011. Student Mobilities, Migration and the Internationalization of Higher Education. Palgrave Macmillan: Basingstoke.

Carey HF, Raciborski R. 2004. Postcolonialism: a valid paradigm for the former Sovietized states and Yugoslavia? East European Politics \& Societies 18: 191-235.

Chankseliani M. 2013. Higher education access in post-Soviet Georgia: overcoming a legacy of corruption. In Fairness in Access to Higher Education in a Global Perspective: Reconciling Excellence, Efficiency, and Justice, Meyer HD, St. John EP, Chankseliani M, Uribe L (eds). SENSE Publisher: Rotterdam; 171-187.

Docquier F, Rapoport H. 2012. Globalization, brain drain, and development. Journal of Economic Literature 50: 681-730.

Economist Intelligence Unit. 2012. Democracy index 2012 democracy at a standstill. Available at: http://www.eiu.com/public/thankyou download.aspx?activity=download\&campaignid =DemocracyIndex12 (accessed 9 May 2014).

Esipova N, Pugliese A. 2013. Desire to leave FSU ranges widely across countries. 
Gallup World. Available at: http://www.gallup.com/poll/161591/desire-leavefsuranges-widely-across-countries.aspx

Favell A. 2008. Rebooting migration theory: interdisciplinarity, globality, and postdisciplinarity in migration studies. In Migration Theory: Talking Across Disciplines, Brettell C, Hollifield J (eds). Routledge: New York; 259-278.

Ferro M. 1997. Colonization: A Global History. Taylor \& Francis: London.

Findlay AM. 2011. An assessment of supply and demand-side theorizations of international student mobility. International Migration 49: 162-190.

Findlay AM, King R, Stam A, Ruiz-Gelices E. 2006. Ever reluctant Europeans. The changing geographies of UK students studying and working abroad. European Urban and Regional Studies 13: 291-318.

Findlay AM, King R, Smith FM, Geddes A, Skeldon R. 2012. World class? An investigation of globalisation, difference and international student mobility. Transactions of the Institute of British Geographers 37: 118-131.

Findlay C, TierneyW. 2010. Introduction and overview. In Globalisation and Tertiary Education in the Asia-Pacific: The Changing Nature of a Dynamic Market, Findlay C, Tierney WG (eds). World Scientific Publishing Co.: River Edge, NJ.

Gibson J, McKenzie D. 2012. The economic consequences of 'brain drain' of the best and brightest: microeconomic evidence from five countries. The Economic Journal 122: 339-375.

González CR, Mesanza RB, Mariel P. 2011. The determinants of international student mobility flows: an empirical study on the Erasmus programme. Higher Education 62: 413-430.

Gribble C. 2008. Policy options for managing international student migration: the sending country's perspective. Journal of Higher Education Policy and Management 30: 25-39.

Grubel HB, Scott AD. 1966. The international flow of human capital. The American Economic Review 56: 268-274.

Haque NU, Kim S-J. 1995. 'Human capital flight': impact of migration on income and growth. Staff Papers - International Monetary Fund 42: 577-607.

Hawthorne L. 2010. Demography, migration and demand for international students. In Globalisation and Tertiary Education in the Asia-Pacific: The Changing Nature of a Dynamic Market, Findlay C, Tierney W (eds). World Scientific Publishing Co.: River Edge, NJ

Hazelkorn E. 2008. Learning to live with league tables and ranking: the experience of institutional leaders. Higher Education Policy 21: 193-215. 
Hazen HD, Alberts HC. 2006. Visitors or immigrants? International students in the United States. Population, Space and Place 12: 201-216.

Johnson HG. 1979. Some economic aspects of the brain drain. Issue: A Journal of Opinion 9: 7-14.

Kappeler A. 2001. The Russian Empire: A Multiethnic History. Pearson Education: Harlow.

Kell P, Vogl G. 2008. Perspectives on mobility, migration and well-being of international students in the Asia Pacific. International Journal of Asia-Pacific Studies 4: v-xviii.

Khalid A. 2007. Introduction: locating the (post-) colonial in Soviet history. Central Asian Survey 26: 465-473.

King R, Conti F. 2013. Bridging the divide: the gap between the study of internal and international migration, with an Italian example. Willy Brandt Series of Working Papers in International Migration and Ethnic Relations. Malmö University, Sweden. Available at:

http://www.mah.se/upload/Forskningscentrum/MIM/Publications/WB\%2013.1.pdf

King R, Raghuram P. 2013. International student migration: mapping the field and new research agendas. Population, Space and Place 19: 127-137.

Kołodziejczyk D, Şandru C. 2012. Introduction: on colonialism, communism and eastcentral Europe - some reflections. Journal of Postcolonial Writing 48: 113-116.

Kritz M. 2013. Sending country determinants of international student mobility. Available at: http://www.iussp.org/en/event/17/programme/paper/5233 (accessed 9 May 2014).

Kritz M. 2015. International student mobility and tertiary education capacity in Africa. International Migration 53(1): 29-49..

Lazarus N. 2012. Spectres haunting: postcommunism and postcolonialism. Journal of Postcolonial Writing 48: 117-129.

Lee KH, Tan JP. 1984. The international flow of third level lesser developed country students to developed countries: determinants and implications. Higher Education 13: 687-707.

Martin M, Bray M. 2009. Tertiary education in small states: development trends and policy implications. International Institute for Educational Planning, Paris.

Massey D. 2003. Patterns and Processes of International Migration in the 21st Century. Paper presented at Conference on African Migration in Comparative Perspective, Johannesburg, South Africa.

Massey D. 2010. Immigration statistics for the twenty first century. The ANNALS of the American Academy of Political and Social Science 631: 124-140. 
Massey D, Arango J, Hugo G, Kouaouci A, Pellegrino A, Taylor JE. 1993. Theories of international migration: a review and appraisal. Population and Development Review 19: 431-466.

McMahon ME. 1992. Higher education in a world market. Higher Education 24: 465482. Middlehurst R. 2001. University challenges: borderless higher education, today and tomorrow. Minerva 39: 3-26.

Miyagiwa K. 1991. Scale economies in education and the brain drain problem. International Economic Review 32: 743-759.

Moore D. 2006. Is the post- in postcolonial the post- in post-Soviet?: Toward a global postcolonial critique. In Baltic Postcolonialism, Kelertas V (ed). Rodopi: New York.

NaidooV. 2007. Declining foreign enrollment at higher education institutions in the United States: a research note. Journal of Studies in International Education 11: 215226.

Perkins R, Neumayer E. 2014. Geographies of educational mobilities: exploring the uneven flows of international students. The Geographical Journal 180(3): 246-259.

President of the Republic of Belarus. 2005. On certain measures aimed to combat trafficking in persons: A decree of the President of the Republic of Belarus, No 3. Available at:

http://www.hsph.harvard.edu/population/trafficking/belarus.traf.05\%282\%29.pdf (accessed 1 May 2014).

Robertson S. 2011. Student switchers and the regulation of residency: the interface of the individual and Australia's immigration regime. Population, Space and Place 17: 103115.

Rosenzweig MR. 2008. Higher education and international migration in Asia: brain circulation. In Annual World Bank Conference on Development Economics 2008, Regional, Lin JY, Pleskovic B (eds). World Bank Publications: Washington, DC.

Sharma Y. 2009. Small states share higher education costs. University World News. Available at: http://www.universityworldnews.com/article.php?story=20090710113541922 (accessed 9 May 2014)

Skeldon R. 2008. International migration as a tool in development policy: a passing phase? Population and Development Review 34: 1-18.

Skocpol T. 1977.Wallerstein's world capitalist system: a theoretical and historical critique. American Journal of Sociology 82: 1075-1090.

Teichler U. 2012. International student mobility in Europe in the context of the Bologna Process. Journal of International Education and Leadership 2(1). Available at: http://www.jielusa.org/wp-content/uploads/2012/01/International-Student-Mobilityin-Europein-the-Context-of-the-Bologna-Process1.pdf 
Todaro MP, Maruszko L. 1987. Illegal migration and US immigration reform: a conceptual framework. Population and Development Review 13: 101-114.

Tremblay K. 2005. Academic mobility and immigration. Journal of Studies in International Education 9: 196-228. UNESCO. 2014a. International flows of mobile students by country of origin - 2012. Available at:

www.uis.unesco.org/Education/Documents/outboundmobility-tableA.xlsx (accessed 29 September 2014).

UNESCO. 2014b. Global flow of tertiary-level students. UIS. Available at: http://www.uis.unesco.org/Education/Pages/international-student-flowviz.aspx UNESCO. 2014c. Higher education. Available at:

http://www.uis.unesco.org/Education/Pages/tertiary-education.aspx (accessed 9 May 2014).

UNESCO. 2014d. Outbound mobility ratio - definition. UIS Glossary. Available at: http://glossary.uis.unesco.org/glossary/en/term/2247/en (accessed 29 September 2014d).

UNESCO. 2014e. Expenditure on education as \% of GDP (from government sources). UNESCO Institute of Statistics. Available at: http://data.uis.unesco.org/index.aspx?queryid=181 (accessed 20 October 2014)

Van Mol C, Timmerman C. 2014. Should I stay or should I go? An analysis of the determinants of intra-European student mobility. Population, Space and Place 20(5): 465-479.

Varghese N. 2008. Globalization of higher education and cross-border student mobility. ENESCO International Institute for Educational Planning, Paris.

Wallerstein I. 1974. The rise and future demise of the world capitalist system: concepts for comparative analysis. Comparative Studies in Society and History 16: 387-415.

Wallerstein I. 1976. Semi-peripheral countries and the contemporary world crisis. Theory and Society 3: 461-483.

Wallerstein I. 2004. World-systems Analysis: An Introduction. Duke University Press: Durham, NC.

Waters J. 2006. Geographies of cultural capital: education, international migration and family strategies between Hong Kong and Canada. Transactions of the Institute of British Geographers 31: 179-192.

Waters J, Brooks R. 2010. Accidental achievers? International higher education, class reproduction and privilege in the experiences of UK students overseas. British Journal of Sociology of Education 31: 217-228.

Wiers-Jenssen J. 2008. Does higher education attained abroad lead to international jobs? Journal of Studies in International Education 12: 101-130. 
Wiers-Jenssen J. 2013. Degree mobility from the Nordic countries: background and employability. Journal of Studies in International Education 17: 471-491.

World Bank. 2013a. World development indicators: explore. Create. Share: development data. Available at: http://databank.worldbank.org/data/home.aspx (accessed 9 May 2014)

World Bank. 2013b. GDP per capita (current US\$). Available at:

http://data.worldbank.org/indicator/ NY.GDP.PCAP.CD (accessed 9 May 2014).

Zolberg AR. 1981. Origins of the modern world system: a missing link. World Politics 33: 253-281. 